\title{
Language Shift among the Arbereshe of Italy
}

\author{
Elsa Pollozhani
}

\begin{abstract}
Throughout history the world has faced migration, occupations, assimilations and explorations that have significantly influenced the way that the world functions today. Humankind has it in its nature to extend and confirm its knowledge. The world has undergone many political and cultural changes through the ages. It has witnessed different world orders, changes of borders and maps, colonization, globalization and similar significant processes. Among the many changes, language is a particular phenomenon that has faced shift, change and many times death. These are common language phenomena that require attention from scholars, researchers and most importantly from decision makers. But how much is being done for the preservation of minority languages? Not enough. Because first of all a language needs institutional and legal protection. This can be done by governments and their linguistic policies. Taking into account actions taken to date, this paper aims to study the under-researched area of Italy's policy towards Arbëresh, a variety of Albanian language spoken by the Albanians of Italy or the Arbëreshë. Arbëresh presents an archaic variant of Albanian, spoken five centuries ago in Albania and has managed to survive in the Albanian communities in Italy, mostly spoken in Calabria and Sicily.
\end{abstract}

Keywords: language, migration, policy, minorities, arbëresh.

\section{Introduction}

Language is the most characteristic component of a nation. Therefore, it should be admitted the fact that language it is not only a mean of communication; it also represents the most important symbol of identity. Without language there is no identity. But, language, being a living organism, the same way it experiences birth and development it also experiences death. The UNESCO Atlas of the World's Languages in Danger lists about 3000 threatened languages to go extinct worldwide. Researchers are monitoring the rapid changes that the threatened languages are undergoing. An important role in the survival of a language plays language contact. Language contact has been and will always be unavoidable. When people come in contact so does language. Some of the reasons that lead to language contact are invasions, migrations, etc. Similar to other people, the Arbëreshë as well have experienced the same fate, and a part of the population was detached from the motherland. Since the paper will elaborate more widely on the case of the Arbëresh language, the study will be preceded by a brief overview of several other cases of languages that experience the same issues.

\section{Language as a social phenomenon}

Although people migrate and settle in other territories, their mother tongue allows them to stay connected to their roots and history. But being in foreign country or maybe living in a country that has another more powerful and more dominant language, people face a lot of difficulties. That is when we face the repercussions of language contact, like language choice, and language shift. Living in a multilingual country is not easy since as a minority language speaker you face difficulties in education, employment and many other situations. Moreover, there are many countries that have practiced more severe limitations for example, in Turkey the extreme was reached and the Kurdish language ${ }^{1}$ was outlawed from public use for some time. But communities vary from one another as some tend to hold on to their language as the Cantonese ${ }^{2}$ has persisted for generations in overseas Chinese communities. Yet, it is believed that people who speak a minority language are still being deceived by society or by the government.

\footnotetext{
Arslan, 2015, pp.16-17

2 Terrazas, Batalova, 2010
} 
Joshua Fishman, an American linguist, published an article in 1964, where he consolidated the terms language "maintenance" and "shift". Language maintenance signifies "the continuing use of a language in the face of competition from a regionally and socially more powerful language", whereas language shift denotes "the replacement of one language by another as the primary means of communication and socialization within a community"1. Language shift implies the decrease in the number of speakers, lower level of proficiency or the extent of the use of the language. Language death occurs when a language loses its speakers, and there remain no native speaker. In most cases, the majority language as the more privileged one, dominates in state institutions, education, health sector, media etc. As a consequence, people who speak a minority language use it only in their personal environment, such as in family situations or around people that speak the same language. This is the case with the first generation of a minority speaking language, they tend to use their mother tongue more, because they are connected to it and they want to preserve it for as long as possible. But then again, the speaker is led to choose the language he or she is going to use. Although they want to speak their mother tongue, they also have to adapt to the language of the majority in order to prosper in a new country. Then in the second generation, although they grow up as bilingual, they often tend to accept the majority language as a first language because they face it in all the main public institutions. So by the third generation the speaker will eventually speak only the majority language, due to the state's absent language maintaining actions. Sometimes it is not only a personal choice as it is also a "submission" to institutional rules. And that is how the minority language is threatened to be used less and less until it is completely lost. There are countless cases representing this issue all around the world.

So by taking into account the phenomenon of language death within three generations we understand that governments influence with their policies the fate of minority language. The governments in some countries put the minority language in a large disadvantage. Fortunately, there are some states that respect and help a minority language by giving autonomy. For example, Norway gave to Sami ${ }^{2}$ considerate linguistic rights, in the regional area of Finnmark, including in government, law and education. By doing this, the Sami people have the possibility to preserve and develop their language. Practicing a mono-linguistic dominance in most of the public institutions leads to a slow but unavoidable language disappearance. This might be seen as an indirect discrimination of a minority group or a minority language. Seeing that public institutions are not welcoming any other language except for the majority language that means that the minority groups are not being acknowledged and their Linguistic Human Rights are being violated.

\section{Language protection laws}

For the preservation of minority languages, a number of special international acts have been adopted. In 2008, the European Union adopted the Resolution on a European strategy for multilingualism ${ }^{3}$. This document consists of a number of obligations for its member states. According to this document the member states are obligated to promote multilingualism with the purpose of enforcing social cohesion, inter-cultural dialogue, economical competition and the possibility of employment within the European market. Even the candidate states of EU and the potential candidates that have applied to become members of EU are obliged to apply these multilingual strategies. These principles ${ }^{4}$ are also being promoted by the "Declaration on the Rights of Persons Belonging to National or Ethnic, Religious and Linguistic Minorities, Resolution of United Nations". Society needs to ensure that these types of resolutions are practically and rightly applied. Practicing multilingualism is being dragged by the bureaucratic traps of different countries.

Precisely, as a result of these international acts, the Arberesh language in Italy has gained the right of language protection by law. Therefore, this paper aims to analyze the specific case of the Arbëresh language in Italy. Italy legally guarantees the right of protection, learning and researching the languages of minorities, with Arbëresh as part of that group. Arbëresh presents an archaic variant of Albanian, which is spoken in Calabria and Sicily, as well as in some other areas of Italy. The law in question is based on the European Charter for Regional or Minority languages ${ }^{5}$, adopted by the Council of Europe in 1992 in Strasburg. This strategy promotes the protection of minority languages and it also encourages their use in public and private life. Even though Italy, signed the resolution in delay in the year 2000, the Italian Parliament is yet to ratify it.

\footnotetext{
1 Mesthrie, Swann, Deumert, Leap, 2009, p.245

2 Action Plan for Sami Languages, 2008

3 Resolution on a European strategy for multilingualism, 2008

4 Declaration on the Rights of Persons Belonging to National or Ethnic Religious and Linguistic Minorities, 1992

5 European Charter for Regional or Minority Rights, 1992-1998
} 
However, with the adoption of the law number $482 / 99^{1}$, which signified the protection of the historic linguistic minorities, the Arbëresh language was also protected by law. Despite not enough actions taken by the government in general, this variant of Albanian language, its preservation and its use deserve a deep and thorough study. It is an archaic variant of Albanian language that was spoken five centuries ago in Albania, before the invasion of the Ottomans and it has not been influenced by the Turkish language as it does not contain any Turkish words, compared to the Albanian language that is today spoken in Albania and by Albanians in the region of the Balkans. This form of Albanian still uses the grammar, sounds and the vocabulary of pre-Ottoman Albania. The word arbëresh is borrowed from Albanian, a rhotic variant of arbënesh (Albanian), from Arbën (Albania, archaic) + esh (-ese, -ish).

\section{Arbëreshë settlements}

Compared to other minorities in the Italian territory, the Arbëreshë case is well documented. ${ }^{2}$ There are data about their origin and their migratory moves. It is important not to confuse the Arbëreshë with the groups that moved to Italy in the last two decades. That was a second large wave around the 1990s that are not identified as Arbëreshë, which migrated as a result of the poor life conditions, the bad economic situation after the fall of the communist regime. The move of the Arbëreshë followed after the death of Gjergj Kastriot Skenderbe, the Albanian national hero. They were scattered throughout villages in the South of Italy. They fled Albania to escape the invasion of the Ottomans. Apart from Italy, there are many Arbëreshë that settled in North and Latin America, mainly in USA, Argentina, Mexico, Chile, Brazil, etc. However, there is one more rather homogenous settlement of the Arbereshe community in Croatia ${ }^{3}$, known as the "Arbanasa of Zadar" or "Arbëreshë of Zadar". The proximate number of the Arbëreshë in Zara is around 4000 . What distinguishes them from the Arbëreshë in Italy is their dialect; their language is based on the gheg dialect, compared to the Arbëreshë of Italy, where the majority is Tosk.

The first large wave of migrants from Albania to Southern Italy was during the fifteenth century when the Ottoman Empire invaded the Balkans. The largest number of these migrants came from the South of Albania, and they were mainly Tosk Albanian refugees. Even though Albanians migrated around five hundred years ago to Italy, they have successfully managed to keep and still use the language, despite being surrounded by Italian language and culture. They have been able to maintain and develop their identities. The Arbëreshë rather than seen as different, should be seen as rich, in language and history. Despite fighting to save their identity, the Arbëreshë have also made a great contribution even to the history of Italy. Even though in smaller number, they were relevant, giving their patriotic contribution for the country of Italy They contributed to the unification of Italy, they were the soldiers of Garibaldi, and they felt as Arbëreshë and at the same time Italians ${ }^{4}$.

\section{The Arbëreshë today}

As it was already emphasized, the Arbëreshë have mainly settled in Calabria and Sicily. They have lived and continue to live in smaller communities, mostly in villages and rural areas. According to the data given by the online library ${ }^{5}$ created by the Arbëreshë living there, and researchers dealing with the Arbëresh language, there are around fifty Arbëresh-speaking communities in Italy. Currently, there are around fifty communities, forty one municipalities and nine villages. The approximate number of the Arbëreshë population is around 88,727, representing one of the largest ethno-linguistic groups in Italy. They have settled across seven regions of Southern Italy: Abruzzo, Molise, Campania, Puglia, Basilicata, Calabria and Sicily. There are 19 municipalities of the Arbëreshë of Calabria in the province of Cosenza while only three municipalities of the Arbëreshë of Sicily in the province of Palermo ${ }^{6}$. They have managed to maintain social, religious and linguistic original traits. At least until the twentieth century, they have been identified as Orthodox and have continued to use Arbëreshë.

Some of these communities have been more determined and able to keep the language, by transmitting it from generation to generation, promoting it and using it. Some communities, even though not connected or not being close to other

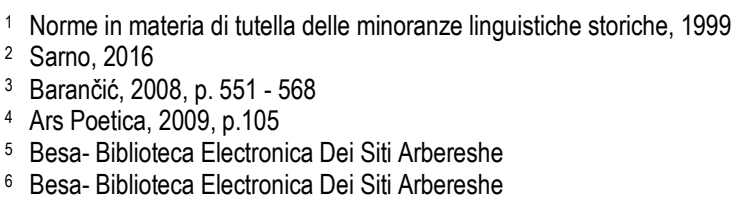


Arbëreshë-speaking communities, they still have managed to keep the language and continue to use it. Other communities have not been able to "resist" to the Italian culture and language. The influence of Italian language is very visible in their language, so, despite having a rich language, they have adopted new words or Italianisms. Certainly, this is a normal phenomenon in minority languages, however, there are different cases, where in some the impact is very low and in others the influence is much bigger. The Arbëreshë, being large in number, scattered in villages, and not facing severe restrictions, concerning the practice of their culture and the use of their language, were able to preserve their identity for more than five centuries. These communities have proved, for over 500 years that they were capable and willing to save their language and culture. They use the Arbëresh language in informal communication, within their household, with other Arbëreshë communities, with Albanians living in Albania, Kosovo, Macedonia, Montenegro and Greece. They have developed an online dictionary, published articles, have written songs that date back to the 1500 s, have continuously celebrated Albanian culture and traditions, through music festivals and other events.

The village of San Marcano ${ }^{1}$ is one of the best examples that prove the preservation and the use of the Arbëresh language. With a population of around 7000, of Albanian origin, it represents an area that, despite being "isolated" and not in direct contact with other Arbëreshë areas in Southern Italy, has never ceased to use the Arbëresh language. Even though, surrounded by Italian culture and language, the Arbëreshë language remains the language of communication among the villagers of San Marcano. Being ruled by Albanian families for a long time, they have contributed in the preservation and the use of the language, its culture and tradition. The language spoken in San Marcano is less studied and less known compared to the language spoken in other Arbëreshë villages, mainly as a result of the lack of writers, yet, it is well preserved.

In a study about the endangerment of Arbëresh Language ${ }^{2}$, it was concluded that half of the communities in Italy have lost their language. In most cases, the features of dialects and cultures have experienced death without being collected or studied, while in those cases that they have managed to maintain the language, the number of speakers has decreased significantly and they use Arbëresh "in restricted situations and settings". Also, some dialects are very close to complete death. Certainly, the phenomenon of language loss is connected with the shift to the dominant language, Italian. As it is the case with many minority languages, in Italy as well, the Arbëresh language faces death. There have continuously been calls by the communities toward the government, to get support in preserving the language and culture. They have addressed the government of Italy as well as the government of Albania, asking for help, to continue to preserve and use the language that they have successfully managed to do for 500 years. They have traditions and customs that even the Albanians in Albania have failed to preserve. The older generations now fear that their successors, the younger generation have little or no knowledge of Arbëresh. Compared to their parents who grew up bilingual, they only speak Italian, because that is the instruction language in schools and Arbëresh is being used less and less.

Another similar case, which represents an example of interest for researchers, is the Albanian enclave in Greece, known as Arvanitas. Hamp (1978) in his comparison of these two cases has concluded that the Arberesh variant of Albanian has more favorable conditions to survive compared to Arvanitika, spoken in Greece. He argues that in Italy people can use a language or dialect other than Italian, and this does not represent an issue or threat to Italian nationalism (as cited in Tsitipis and Elmendorf). While in Greece "no form of linguistic autonomy has ever been recognized to various localities..."3, therefore, this does not allow for any other language to be accepted as a language of a minority. With an estimated number of 200,000 , the Arvanites, can be found mainly in southeastern Greece. Initially settled in the villages, similar to their counterpart in Italy, eventually, Arvanites moved to cities, and this migration within the borders of the country largely contributed to the language shift among Arvanite speakers of younger generations.

Taking into account the causes of language shift and in certain cases language death, recommendations of conventions cited in the text, and multilingual strategies should be supported to great extent. In March 2013, Rita Izsák ${ }^{4}$, UN Independent Expert on minority issues, said that "protection of linguistic minority rights is a human rights obligation and an essential component of good governance, efforts to prevent tensions and conflict, and the construction of equal and politically and socially stable societies". If a minority language isn't being acknowledged then the communities will consequently face

\footnotetext{
Shkurtaj, 2013

Derhemi, 2002

3 Tsitsipis and Elmendorf, 1983

4 Izsak, 2013
} 
tension among groups. Language maintenance is also dependent on political realities. In the end, it is not only a matter of personal choice, but it is also a matter of politics that regulates the use of language.

\section{Conclusion}

Taking the name Arbëreshë since at the period they left Albania the country was called Arbëria, they represent the Albanian community that was most successful at preserving the language, the traditional clothes and Christian Orthodox-byzantine religious rites. Organized in smaller communities, initially in villages and later in cities as well, the Arbëreshë have created conditions for the continuous use of their language. Recognized as "the language of ethno-linguistic minority", included in certain university departments of linguistic minorities, available in the radio, magazines, cultural, musical and theatrical events, in traffic signs and signals, the Arbëresh language, to a certain extent has overcome the challenges of time. Yet, the insufficient action of the decision makers has largely influenced the fate of the Arbëreshë. With the migration of Arbëreshë in most developed cities and neighboring countries and the decrease of number of speakers, these communities have already experienced language shift and now fear the phenomenon of language death. For this reason, calls requesting support and initiatives have been very frequent. Therefore, governments should be thinking of ways that they can reverse language shift because by preserving the language that will also preserve a culture that may be threatened to disappear.

The above-mentioned convents should be implemented by every country that within their territories have minorities and languages facing extinction. In order for a minority language to continue to be used it needs the action of political groups, it needs the initiative to try to save its traditions and culture. Moreover, it needs protection from institutions as well as commitment and efforts by the communities that face language shift or language death. Despite the large number of nongovernmental organizations that make great efforts to help languages that are facing extinction, still, the involvement and the action of the government is indispensable. Governmental institutions not only offer legal protection; at the same time they posses all the required financial possibilities in order to obtain the needed infrastructure for the survival of an endangered language.

\section{Bibliography}

[1] Ars Poetica, Number.17 2009

[2] Arslan, Sevda, 2015, Language Policy in Turkey and Its Effect on the Kurdish Language, Retrieved from

[3] https://scholarworks.wmich.edu/cgi/viewcontent.cgi?referer=https://www.google.com/\&httpsredir=1\&article=16 30\&context=masters_theses

[4] Barančić, Maximiljana, 2008, Arbanasi i etnojezični identitet, Croatica et Slavica ladertina, IV, Zadar

[5] Council of the European Union, 2008, Resolution on a European strategy for multilingualism, Retrieved from

[6] http://eur-lex.europa.eu/legal-content/EN/ALL/?uri=CELEX\%3A32008G1216(01)

[7] Derhemi, Eda, 2002. The Endangered Arbresh Language and the Importance of Standardised Writing for its Survival: The Case of Piana degli Albanesi, Sicily.

[8] http://citeseerx.ist.psu.edu/viewdoc/download?doi=10.1.1.575.4657\&rep=rep1\&type=pdf

[9] Gazzeta Ufficiale, Norme in materia di tutella delle minoranze linguistiche storiche, 1999, Retrieved from

[10] http://www.camera.it/parlam/leggi/99482l.htm

[11] Izsák, Rita, 2013, Protection of minority languages is a human rights obligation, Retrieved from

[12] http://www.lavplu.eu/central/bibliografie/un_minority_human_rights.pdf

[13] Mesthrie, Rajend, Joan, Swann, Ana Deumert, William L. Leap, Introducing Sociolinguistics, 2009, Retrieved from

[14] http://home.lu.Iv/ pva/Sociolingvistika/0710892_68436_mesthrie_rajend_et_al_introducing_sociolinguistics.pd $f$

[15] Norwegian Ministry of Labour and Social Inclusion, Action Plan for Sami Languages, 2008, Retrieved from,

[16] https://www.regjeringen.no/globalassets/upload/fad/vedlegg/sami/hp_2009_samisk_sprak_engelsk.pdf

[17] Sarno, Stefania, 2016. Shared language, diverging genetic histories: high-resolution analysis of Y-chromosome variability in Calabrian and Sicilian Arbereshe, Retrieved from

[18] https://scholarworks.wmich.edu/cgi/viewcontent.cgi?referer=https://www.google.com/\&httpsredir=1\&article=16 30\&context=masters_theses

[19] Shkurtaj, Gjovalin, 2013, Ligjerimet Arbereshe, "Gjuha e bukës" dhe "gjuha e zemrës"

[20] Terrazas Aaron and Jeanne Batalova, 2010, Chinese Immigrants in the United States, Retrieved from 
[21] https://www.migrationpolicy.org/article/chinese-immigrants-united-states-0

[22] Tsitsipis, D. Lukas, and Elmendorf, W. William, 1983, Language Shift among the Albanian Speakers of Greece

[23] https://www.jstor.org/stable/30027674?read-now=1\&seq=1\#page_scan_tab_contents

[24] United Nations. (1992). Declaration on the Rights of Persons Belonging to National or Ethnic, Religious and Linguistic Minorities, Resolution of United Nations 1992, Retrieved from

[25] http://www.ohchr.org-/EN/Professionallnterest/Pages/Minorities.aspx 